\title{
Cluster analysis of acoustic emission signals from the friction zone of tribosystems
}

\author{
K.A. Fenenko \\ Petro Vasylenko Kharkiv National Technical University of Agriculture, Kharkiv, Ukraine \\ E-mail:vavoitovva@gmail.com
}

\begin{abstract}
The directions of the use of the method of acoustic emission (AE) for the study of stationary and transient processes in tribosystems during the operation have been considered here. It has been shown that the application of this method will allow obtaining information about the state of friction surfaces and the rate of wear during transients (running-in) processing online.

To substantiate the choice of the informative parameters of AE, the cluster analysis of the frames of $\mathrm{AE}$ signals from the friction zone of the tribosystem with the separation of the signal into the groups of the sources of its generation has been performed. The correlation dependence between the friction coefficient $f_{\text {тр }}$ and the values of the peak factor of cluster K2, the correlation coefficient $r=0.99$, and the rate of volumetric wear I, $\mathrm{m}^{3} / \mathrm{h}$, and the values of the peak factor of cluster K3, the correlation coefficient $r=0.99$ have been established. The values of the peak factor of cluster K4 correlate with the rate of volumetric wear during the running-in, the correlation coefficient $r=0.98$.

It has been experimentally confirmed that the cluster analysis of acoustic emission signals from the friction zone of the tribosystem allows one to identify the surface processes during wear, thereby increasing the robustness and information content of the AE method. This analysis can serve as the basis for the development of a diagnostic technique for tribosystems during their operation, which will make it possible to measure the wear rate at any time and calculate the tribosystem resource.
\end{abstract}

Key words: tribosystem; wear rate; coefficient of friction; acoustic emission; cluster analysis; peak factor; transient processes; running-in.

\section{Introduction}

The acoustic vibrations that the tribosystem generates during operation arise due to the impact interaction of the roughness of the friction surfaces of their elastoplastic deformation, the processes of the formation and destruction of frictional bonds (stick-sleep mode [1]), structural-phase rearrangement of materials, the formation and development of micro-cracks in the surface layers of the contacting bodies, the separation of wear particles. The registration of acoustic signals makes it possible to determine with high accuracy the time of the occurring events, which include the elastic interaction of micro-protrusions of the mating surfaces, the formation and destruction of adhesive bonds, the appearance of micro-cracks and the separation of wear particles.

The first publications on the use of acoustic emission (AE), as a method for diagnosing friction units, appeared in the late $1970 \mathrm{~s}$, as a way to diagnose friction and wear processes. With the modern development of signal registration tools, the use of this method allows one to obtain information about the state of friction surfaces online.

\section{Literature review}

The author of the work [2] has analysed the publications on the use of AE for diagnosing various tribosystems. The author concludes that studies on acoustic emission diagnostics of mechanisms are based on the use of signs of discrete emission: counting (the number of impulses registered during the entire test period); activity (the number of impulses per time unit) [3]. As for continuous emission (when it is impossible to distin- 
guish between individual impulses), it is characterized by the parameters widely used in vibrational diagnostics - mean-square deviation, peak factor, and vibration spectrum [4]. In addition, time parameters are used (the duration of the front and decay of impulses) [4], the parameters of the distribution of impulses in amplitude and the wavelet transformation [5].

Based on the analysis of the works of Western scientists [6-11], in [12] it is concluded that a promising direction is the justification of acoustic emission signs of defects that are invariant to signal scaling by amplitude. This is due to the fact that signal fluctuations, the differences in the amplitude-frequency characteristics of the sensors affect the result of measuring the energy parameters of the emission, such as energy, the average value of the amplitudes, the spectrum and the result of the wavelet transformation. The listed factors affect the parameters of the registered acoustic emission signal. According to the author of [12], when measuring the temporal parameters of acoustic emission, it is advisable to choose a threshold level of amplitudes, which is determined from the conditions of the minimum probability of a diagnostic error.

To determine the maximum values of the wear rate during the transition process, the authors of [13] have substantiated an informative parameter - the power of AE signals. The authors showed that the power of AE correlates with the wear rate, the correlation coefficient $\mathrm{R}=0.98$ and it adequately reflects the running-in process.

Based on the analysis of the works devoted to the selection of informative AE parameters for the diagnosis of tribosystems, it can be concluded that to determine the wear rate and the friction coefficient during the operation of the tribosystem (online), the most promising approach may be the separation of the AE signal into components - clusters. The analysis of each cluster will make it possible to obtain information about a separate group of processes occurring in the surface layers of the materials of the tribosystem, which will increase the robustness of this method and the information content of diagnosing tribosystems.

\section{Purpose}

The purpose of this study is to develop a methodology for analysing AE signal frames from the friction zone of the tribosystem with separating the signal into the groups of the sources of its generation, which will allow diagnosing friction and wear processes.

\section{Methods}

To justify the selection of informative parameters for analysing the frame of AE signals from the friction zone, let us use the notion of cluster. The cluster (aggregation) is the union of several homogeneous elements which can be considered as an independent unit. In our case, during the analysis of the AE signal frame, this is a subset of the same type of impulses with the same values of the amplitudes $\mathrm{A}_{\mathrm{i}}$ connected by the same generation sources.

Based on this definition, the AE signal frame, which is shown in Fig. 1, can be divided into four clusters

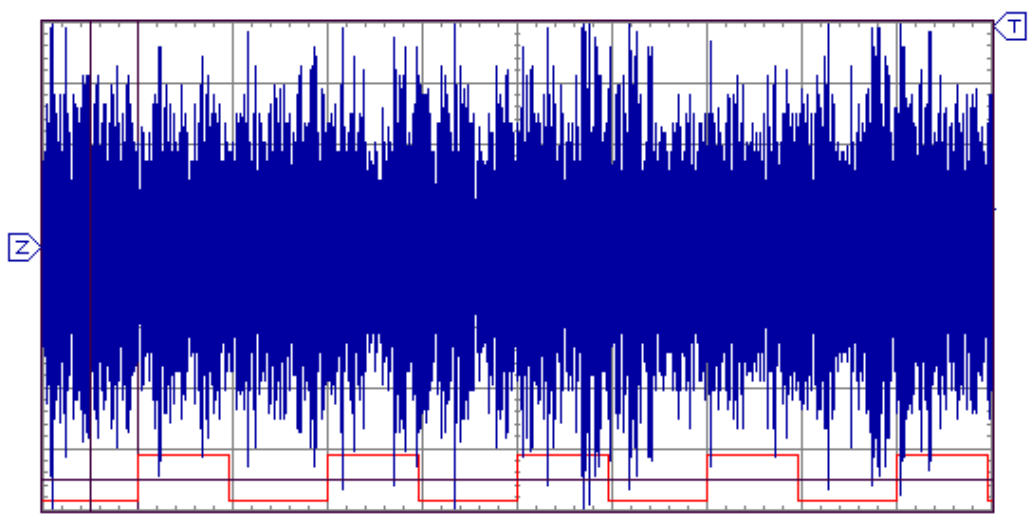

Fig. 1. The AE signal frame the operation of the tribosystem

The first cluster, Fig. 2, is a basic pack of AE signals or a basic frame. The sources for generating the basic signal pack are: the slide of dislocations during the deformation of surface layers on the spots of the actual contact; the inter-granular slide; the rotation of blocks (granules); the twinning; the structural adjustment (the phase transformations due to high temperatures on the spots of the actual contact).

The energy or power of the AE signal of the first cluster - K1 can be estimated using the value of the amplitudes $-A_{1}$. After passing the analogue signal of $A E$ through the analogue-to-digital converter, the amplitude values can be represented as discrete values of rectangular impulses.

The peak factor of a random sequence of discrete $\mathrm{AE}-\mathrm{P}_{\mathrm{AE}}$ signals is defined as the ratio of peak power to average power of the signal and can be generally written as follows [14]: 


$$
P_{A E}=\frac{W_{\max }}{W_{c p}}=\frac{\max |A(t)|^{2}}{\frac{1}{T} \int|A(t)|^{2}},
$$

where $\mathrm{W}_{\max }$ - the maximum value of the peak power of the $\mathrm{AE}$ signal;

$\mathrm{W}_{\mathrm{cp}}$ - the average value of the $\mathrm{AE}$ signal power;

$\mathrm{A}(\mathrm{t})$ - the signal amplitude value when changing the registration time; $\mathrm{T}$ - the duration of the frame registration.

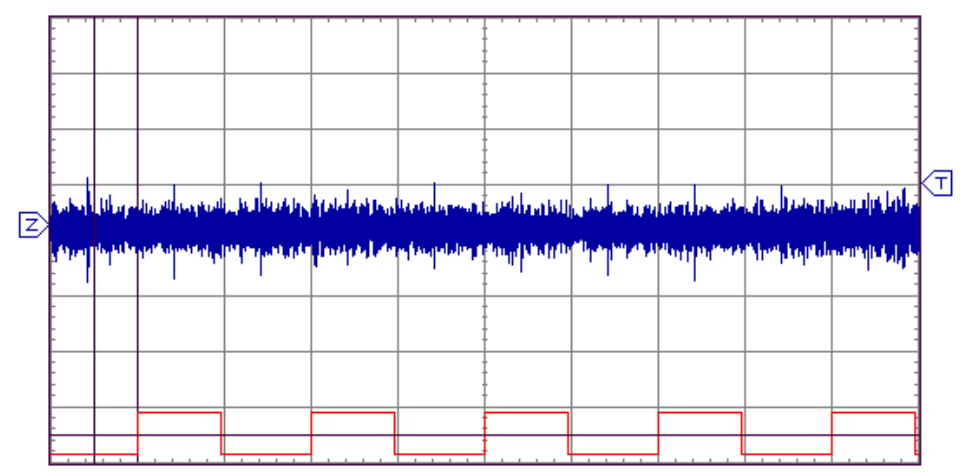

Fig. 2. AE signals frame of the first cluster K1 during the operation of the tribosystem

For the signal after the analogue-to-digital converter, expression (1) can be written [14]:

$$
P_{A E}=\frac{\max |A(t)|^{2}}{W_{c p}}=\frac{\left\langle\sum_{n=1}^{n} \sum_{m=1}^{m}\left(A_{n} \cdot A_{m}\right)\right\rangle}{\sum_{n=1}^{n}\left|A_{n}\right|^{2}},
$$

where $\mathrm{n}$ - the number of impulses of the AE signal that are contained in the frame;

$\mathrm{m}$ - the number of impulses of the AE signal that exceed the average value of the amplitudes;

$A_{n}$ - the values of the amplitudes of all AE impulses belonging to the frame;

$\mathrm{A}_{\mathrm{m}}$ - the values of the amplitudes of the AE impulses belonging to the frame, which exceed the average value of the amplitudes.

Based on expression (2), let us write the formula for calculating the peak factor of cluster K1:

$$
P_{A \ni}^{K 1}=\frac{\max \left|A_{1}(t)\right|^{2}}{W_{c p}}=\frac{\left\langle\sum_{n=1}^{n} \sum_{m=1}^{m}\left(A_{1} \cdot A_{\max , 1}\right)\right\rangle}{\sum_{n=1}^{n}\left|A_{1}\right|^{2}},
$$

where $A_{1}$ - the values of the amplitudes of all $\mathrm{AE}$ impulses belonging to the frame of cluster $\mathrm{K} 1$;

$\mathrm{A}_{\max , 1}$ - the values of the amplitudes of $\mathrm{AE}$ impulses belonging to the frame of cluster $\mathrm{K} 1$, which exceed the average value of the amplitudes in the cluster.

The second cluster, Fig. 3, is a pack of AE signals, which is characterized by spikes in amplitudes the values of which exceed the average value of the amplitudes of the first (basic) cluster K1 by $2.4 \ldots 2.8$ times.

The sources of the signal generation for cluster K2 are: deformation jumps on the spots of the actual contact as a result of which slide strips form; the jump-like movement of the protrusions of the roughness due to the change in the adhesion forces, which in [1] was called the stick-sleep mode. 


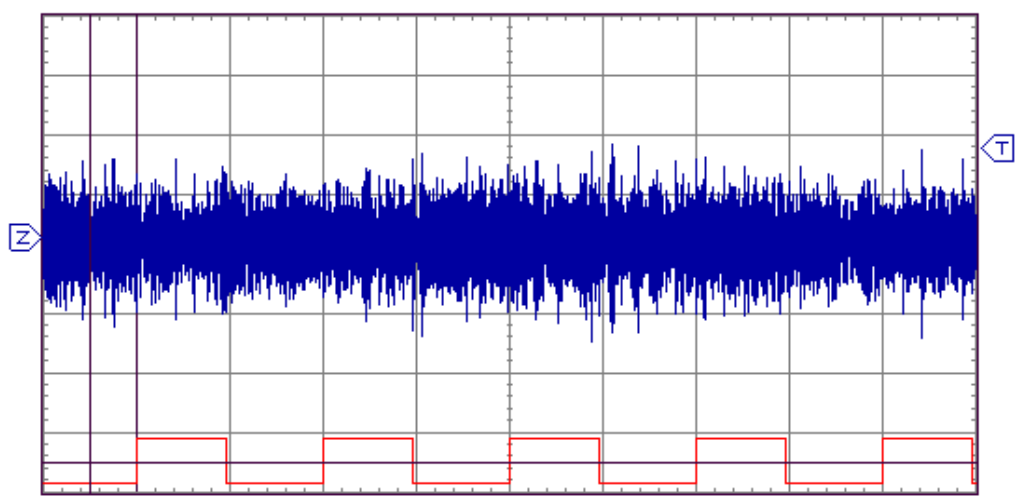

Fig. 3. The frame of AE signals of the second cluster K2 during the operation of the tribosystem

Based on expression (2), let us write the formula for calculating the peak factor of cluster K2:

$$
P_{A \ni}^{K 2}=\frac{\max \left|A_{2}(t)\right|^{2}}{W_{c p}}=\frac{\left\langle\sum_{n=1}^{n} \sum_{m=1}^{m}\left(A_{1} \cdot A_{\max , 2}\right)\right\rangle}{\sum_{n=1}^{n}\left|A_{1}\right|^{2}},
$$

where $\mathrm{A}_{1}$ - the value of the amplitudes of all $\mathrm{AE}$ impulses belonging to the frame of cluster $\mathrm{K} 1$;

$A_{\max 2}$ - the values of the amplitudes of AE impulses belonging to the frame of cluster $\mathrm{K} 2$, which exceed the average value of the amplitudes in cluster $\mathrm{K} 1$ by $2.4 \ldots 2.8$ times.

The third cluster, Fig. 4, is a pack of AE signals, which is characterized by spikes of amplitudes the values of which exceed the average value of the amplitudes of the first (basic) cluster K1 by $4.2 \ldots 4.6$ times.

The sources of the signal generation for cluster K3 are: the formation of fatigue cracks in parallel and perpendicular to the friction surface; the separation of wear particles from the friction surface in the form of flakes or petals by the mechanism of fatigue wear; the separation of wear particles from the friction surface by the mechanism of "sliding-out" of oxide films or secondary structures.

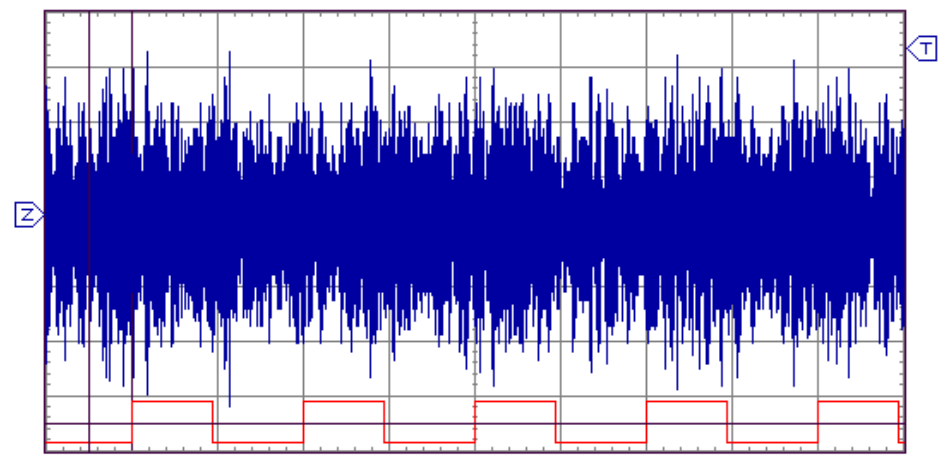

Fig. 4. AE signals frame of the third $\mathrm{K} 3$ cluster during the tribosystem operation

Based on expression (2), let us write the formula for calculating the peak factor of cluster K3:

$$
P_{A \ni}^{K 3}=\frac{\max \left|A_{3}(t)\right|^{2}}{W_{c p}}=\frac{\left\langle\sum_{n=1}^{n} \sum_{m=1}^{m}\left(A_{1} \cdot A_{\max , 3}\right)\right\rangle}{\sum_{n=1}^{n}\left|A_{1}\right|^{2}},
$$

where $A_{1}$ - the values of the amplitudes of all AE impulses belonging to the frame of cluster $\mathrm{K} 1$;

$\mathrm{A}_{\max , 3}$ - the values of the amplitudes of $\mathrm{AE}$ impulses belonging to the frame of cluster $\mathrm{K} 3$, which exceed the average value of the amplitudes in cluster $\mathrm{K} 1$ by $4.2 \ldots 4.6$ times. 
The fourth cluster, Fig. 1, is a pack of AE signals, which is characterized by emissions of large amplitudes, the values of which exceed the average value of the amplitudes of the first (basic) cluster K1 by 5.4 ... 5.8 times.

The sources of the signal generation for cluster K4 are: micro-cutting and plastic crushing of the protrusions of the friction surface roughness, which is characteristic of the first stages of running-in.

Based on expression (2), let us write the formula for calculating the peak factor of cluster K4:

$$
P_{A \ni}^{K 4}=\frac{\max \left|A_{4}(t)\right|^{2}}{W_{c p}}=\frac{\left\langle\sum_{n=1}^{n} \sum_{m=1}^{m}\left(A_{1} \cdot A_{\max , 4}\right)\right\rangle}{\sum_{n=1}^{n}\left|A_{1}\right|^{2}},
$$

where $\mathrm{A}_{1}$ - the values of the amplitudes of all AE impulses belonging to the frame of cluster $\mathrm{K} 1$;

$\mathrm{A}_{\text {max, }}$ - the values of the amplitudes of the AE impulses belonging to the frame of cluster $\mathrm{K} 4$, which exceed the average value of the amplitudes in cluster $\mathrm{K} 1$ by $5.4 \ldots 5.8$ times.

The overlapping of all four frames one on one gives the total form of the AE signal frame during the operation of the tribosystem, which is shown in Fig. 1.

\section{Results}

The experimental studies were carried out on a friction machine according to the kinematic "ring-ring" scheme under the following conditions: a mobile triboelement steel $40 \mathrm{H}$ ( $45 \ldots 47 \mathrm{HRC})$, a stationary triboelement Br.AZh 9-4 (90 ... $110 \mathrm{HB})$. The lubricating medium - engine oil $\mathrm{M}-10 \mathrm{G}_{2 \mathrm{k}}\left(\mathrm{E}_{\mathrm{y}}=3.6 \cdot 10^{14} \mathrm{~J} / \mathrm{m}^{3}\right)$.

The block diagram of the experimental equipment for registering and processing AE signals from the friction zone is shown in Fig. 5.

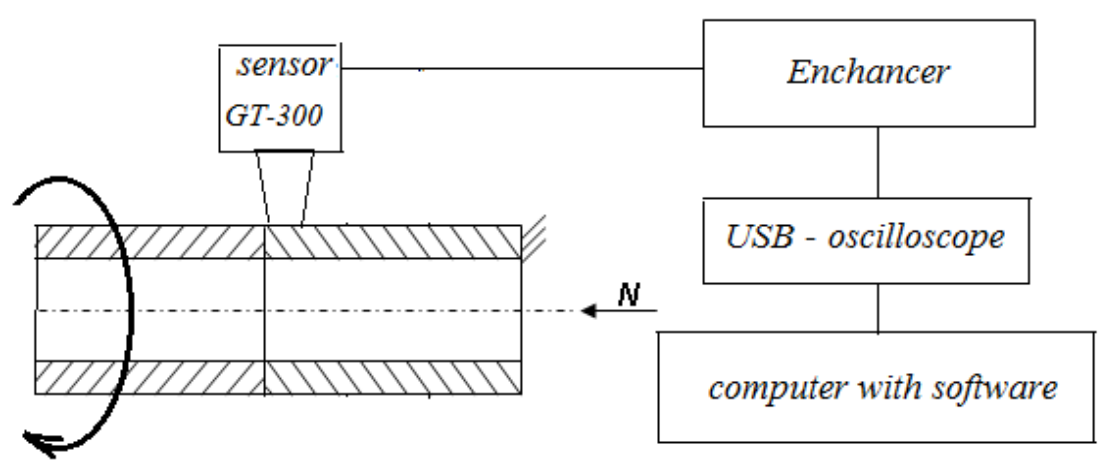

Fig. 5. Block diagram of experimental equipment for recording and processing AE signals

The AE signal from the friction zone is registered by the GT300 broadband sensor (100..800 kHz), Fig. 5, which was mounted on a stationary triboelement, and is transmitted to the amplifier, then, in the analogue form, to the PV6501 USB-oscilloscope, which performs the functions of the analogue-to-digital converter. After being processed in the USB-oscilloscope, the signal in a digital code enters the computer, where it is processed by special software. The result of processing is the calculation of peak factors for the four clusters according to formulas (3) - (6).

The amplifier, Fig. 5, consists of an input stage, a filter of low and high frequencies with an adjustable transmission coefficient ( $1 \ldots$ 100). The total gain is 1000 . The lower passband of the signal is $50 \mathrm{kHz}$, which does not allow registering signals from the test equipment (the friction machine). The upper passband of the signal is $1,5 \mathrm{MHz}$. Such a frequency range was selected based on the analysis of the other authors' works which are devoted to acoustic emission from the friction zone [2-14].

The passband of the USB oscilloscope, Fig. 5, is $20 \mathrm{MHz}$, which is many times higher than the selected working passband and signal registering. Thus, with the help of low and high frequency filters during the performed research the AE signal from the friction zone in the band of 50-1500 kHz has been registered and analysed.

The USB oscilloscope works in a standby mode and starts by command for a registration time of $1000 \mu \mathrm{s}$. Such a time was selected based on the analysis of the AE signal at a set mode using the autocorrelation function.

The results of AE signals in a digital code are accumulated and stored in computer memory in separate files, and then processed with the determination of the total value of the squared amplitudes during the registra- 
tion of $\mathrm{A}^{2}$, the variance and standard deviation of $\mathrm{A}^{2}$, the peak factors values for the first - fourth clusters using formulas (3) - (6).

When checking the homogeneity of the variances of the selected AE signal frames at the set operating mode of the tribosystem, as well as the reproducibility of the results from frame to frame, ISO 5725 standard recommends using the Cochrane criterion. The Cochrane criterion allows one to compare the uniformity of variances of the results of the analysis of AE signals from different frames.

The test statistics of the Cochrane criterion $\mathrm{C}_{\mathrm{p}}$ is determined by the expression:

$$
C_{p}=\frac{D_{A \max }}{\sum_{i=1}^{n} D_{A i}},
$$

where $D_{\text {Amax }}$ - the maximum value of the variance of the amplitudes of the AE signals at the set mode of friction;

$\mathrm{n}$ - the number of measurements;

$D_{A i}$ - the current value of the variance according to the i-th experiment.

According to ISO 5725 standard, the hypothesis of homogeneity (reproducibility) is verified by the following expression:

$$
C_{p}<C_{m}
$$

where $C_{p}$ - the calculated value of the Cochrane criterion, formula (7);

$C_{m}$ - the tabular value of the criterion for the given level of significance [15]. accepted.

If condition (8) is satisfied, then the hypothesis of statistical homogeneity of the measurements results is

The experimental studies were carried out with the following friction modes: load $\mathrm{N}=500 \ldots 2000 \mathrm{~N}$; slide speed $0.5 \mathrm{~m} / \mathrm{s}$. In the course of the experiments, the volumetric wear of the mobile and stationary triboelements (using the artificial base method) and the friction moment, which were converted into the volumetric rate of wear and friction coefficient, have been registered.

The experimental research aimed to confirm the correlation between the volumetric wear rate of the tribosystem $\mathrm{I}, \mathrm{m}^{3} /$ hour and the friction coefficient $\mathrm{f}_{\mathrm{fr}}$ with the peak factors of various clusters, which are calculated by formulas (3) - (6).

The results of the experimental research are presented in Fig. 6, and they display the average values of the volumetric wear rate and the friction coefficient at the set mode of operation of the tribosystem (after the completion of running-in) at different loads, as well as the calculated values of the peak factors for the three clusters of AE signals from the friction zone.

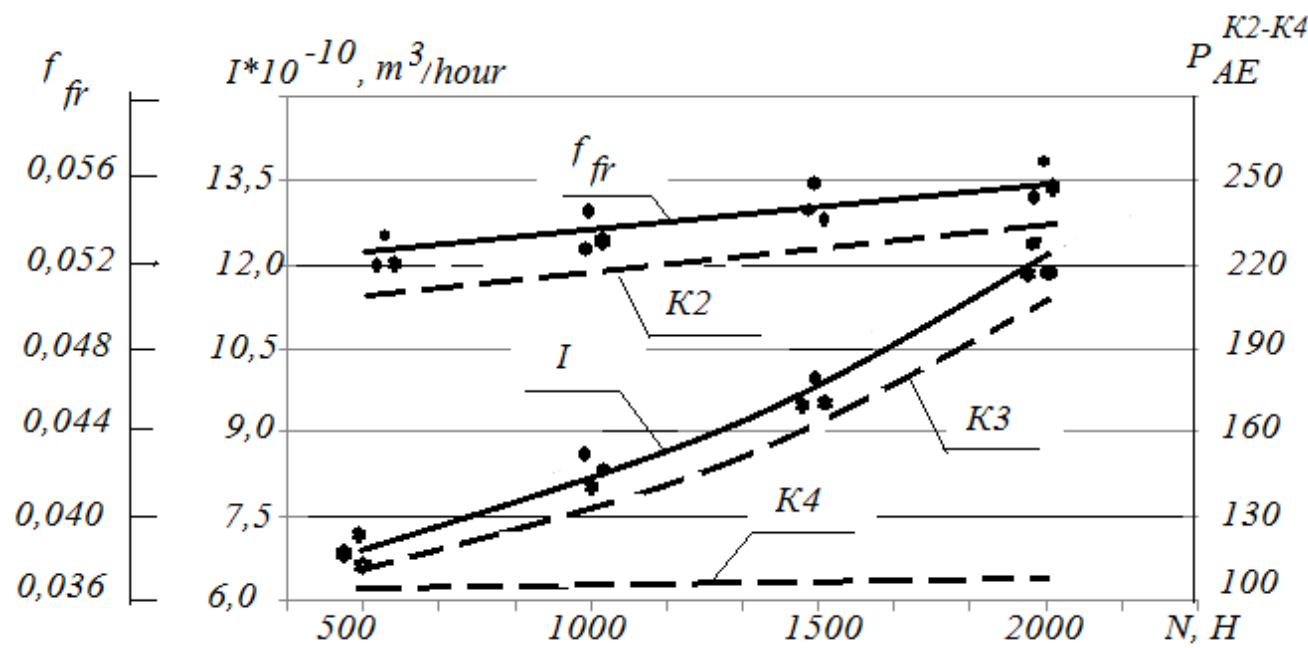

Fig. 6. Dependences of the change in the volumetric wear rate $I$, the friction coefficient $f_{\text {frr }}$, and the calculated values of the $\mathrm{AE}$ peak factor of various $\mathrm{P}_{\mathrm{AE}}$ clusters with a change in $\mathrm{N}$ load on the tribosystem 
The analysis of the obtained dependences allows one to state that there is the presence of a correlation between: the friction coefficient $f_{\text {fr }}$ and the values of the peak factor of cluster $\mathrm{K} 2$, the correlation coefficient $r=$ 0,99 ; the rate of volumetric wear $\mathrm{I}, \mathrm{m}^{3} / \mathrm{h}$ and the values of the peak factor of cluster $\mathrm{K} 3$, the correlation coefficient $r=0.99$. The values of the peak factor of cluster $\mathrm{K} 4$ do not correlate with the above tribological characteristics.

To establish a correlation between the tribological characteristics and the peak factor of cluster K4, the AE signals were registered during the operation of the tribosystem during running-in, Fig. 7.

The analysis of the obtained dependences allows one to state that there is the presence of a correlation between the volumetric wear rate $\mathrm{I}, \mathrm{m}^{3} / \mathrm{h}$ during running-in and the values of the peak factor of cluster $\mathrm{K} 4$, the correlation coefficient $r=0.98$.

The evaluation of the reproducibility of the results of measuring AE signals at various loads, followed by the calculation of the Cochrane criterion, has showed that the parameters of AE signals during the operation of the tribosystem at different loads are homogeneous and reproducible.

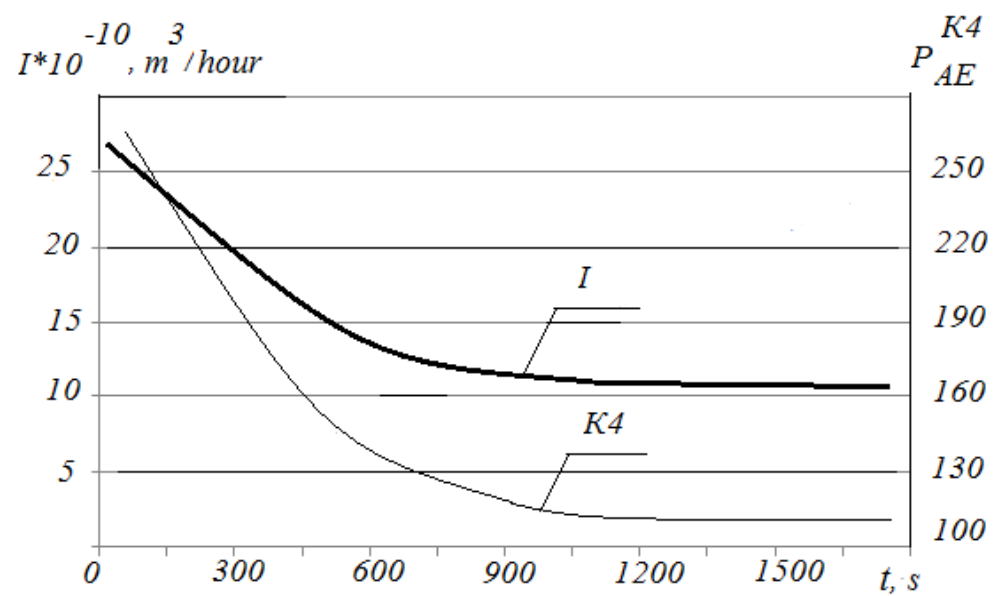

Fig. 7. Dependences of the change in the volumetric wear rate $I$ and the calculated values of the peak factor of the $\mathrm{AE}$ cluster K4 during running-in at a load of $\mathrm{N}=1500 \mathrm{H}$

Analysing the presented dependences in Fig. 6 and 7, one can make a conclusion that the cluster analysis of acoustic emission signals from the friction zone of the tribosystem allows one to identify surface processes during wear, thereby increasing the robustness and information content of the AE method. This analysis can serve as the basis for the development of a methodology for diagnosing tribosystems during their operation, which will make it possible to measure the wear rate at any time and calculate the service life of the tribosystem.

\section{Conclusions}

The cluster analysis of AE signal frames from the friction zone of the tribosystem has been performed with the signal separated into groups of sources of its generation. The correlation dependence has been established between the friction coefficient $\mathrm{f}_{\mathrm{fr}}$ and the values of the peak factor of cluster $\mathrm{K} 2$, the correlation coefficient $r=0.99$, as well as with the volumetric wear rate $\mathrm{I}, \mathrm{m}^{3} / \mathrm{h}$ and the values of the peak factor of cluster $\mathrm{K} 3$, the correlation coefficient $r=0.99$. The values of the peak factor of cluster $\mathrm{K} 4$ correlate with the rate of volumetric wear during running-in, the correlation coefficient $r=0.98$.

The cluster analysis of acoustic emission signals from the friction zone of the tribosystem allows one to identify surface processes during wear, thereby increasing the robustness and information content of the $\mathrm{AE}$ method. This analysis can serve as the basis for the development of a methodology for diagnosing tribosystems during their operation, which will make it possible to measure the wear rate at any moment of time and calculate the service life of the tribosystem.

\section{References}

1. Ferrer C., Salas F., Pascal M., Orozco J. Descrete acoustic emission waves during stick-slip friction between steel samples, Tribology International, 2010, No.43, pp.1-6. [English]

2. Shevchenko S.A.. Classification and justification of requirements for acoustic emission characteristics of friction pairs defects of mechanisms, Bulletin of Kharkiv National Technical University of Agriculture named after P. Vasylenko, 2012, No.121, p.159-163. [Ukraine]

3. Abdullah M., D. Al-Ghamd, Zhechkov, D. Mba. A comparative experimental study on the use of Acoustic Emission and vibration analysis for bearing defect identification and estimation of defect size, Mechanical System and Signal Processing, 2006, No.7, pp.1537-1571. [English] 
4. Mazal P., V.Koula, F.Hort, F.Vlasic. Applications of continuous sampling of AE signal for detection of fatigue damage, NDT in Progress, 2009, No.4. -8 p. [English]

5. Yanhui Feng. Discrete wavelet-based thresholding study on acoustic emission signals to detect bearing defect on a rotating machine, The Thirteen International Congress of Sound and Vibration. Vienna, Austria, 2-6 July, 2006. -8 p. [English]

6. Faris Elasha., Matthew Greaves, David Mba, Abdulmajid Addali. Application of Acoustic Emission in Diagnostic of Bearing Faults within a Helicopter gearbox, The Fourth International Conference on Through-life Engineering Services. Procedia CIRP, 2015, Vol.38, pp. 30-36. [English]

7. Seyed A. Niknam, Tomcy Thomas, J. Wesley Hines, Rapinder Sawhney. Analysis of Acoustic Emission Data for Bearings subject to Unbalance, International Journal of Prognostics and Health Management, 2013, Vol. 15, pp. 1-10. [English]

8. Badgujar M.P., Patil A.V. Fault Diagnosis of Roller Bearing Using Acoustic Emission Technique and Fuzzy Logic, International Journal of Latest Trends in Engineering and Technology, 2014,Vol. 3, Issue 4, pp.170-175. [English]

9. Rao V.V., Ratnam Ch. A Comparative Experimental Study on Identification of Defect Severity in Rolling Element Bearings using Acoustic Emission and Vibration Analysis, Tribology in Industry, 2015 , Vol. 37, No. 2, pp.176-185. [English]

10. Zahari Taha., Indro Pranoto. Acoustic Emission - Research and Applications. Chapter 4 - Acoustic Emission Application for Monitoring Bearing Defects, InTech. 2013, pp.71-90. http://dx.doi.org/10.5772/55434 [English]

11. Nienhaus K., Boos F.D., Garate K., Baltes R. Development of Acoustic Emission (AE) based defect parameters for slow rotating roller bearings, Journal of Physics: Conference Series. 364. 2012. 012034. 1-10. doi:10.1088/1742-6596/364/1/012034 [English]

12. Yongyong He., Xinming Zhang, Michael I. Friswell. Defect Diagnosis for Rolling Element Bearings Using Acoustic Emission, Journal of Vibration and Acoustics, 2009, Vol. 131 / 061012. [English]

13. Voitov V.A., Biekirov, A. Sh., Voitov A.V. Choice of informative acoustic emission parameters for determining the wear rate of tribosystems in transient modes. Technical service of agriculture, forestry and transport systems 2019. № 15. p. 190-202. [Ukraine]

14. Chechel'nitskii V.Y., Troyansky A.V. Peak factor of multi-frequency noise-like signals encoded by equivalent classes of modern binary gratings, Proceedings of Odessa Polytechnic University, 2005, No.2(24), p.181-186. [Russian]

15. Zagigaev L.S., Kishiyan A.A., Romanikov Y.I. Methods of planning and processing the results of a physical experiment, M.: Atomizdat, 1978. - 232 p. [Russian] 
Фененко К.А. Кластерний аналіз сигналів акустичної емісії із зони тертя трибосистем

Розглянуті напрямки застосування методу акустичної емісії (АЕ) для дослідження стаціонарних та перехідних процесів в трибосистемах під час експлуатації. Показано, що застосування такого методу дозволить отримувати інформацію про стан поверхонь тертя та швидкість зношування під час перехідних процесів (припрацювання) в онлайн-режимі.

Для обгрунтування вибору інформативних параметрів АЕ виконаний кластерний аналізу фреймів сигналів AЕ із зони тертя трибосистеми з поділом сигналу на групи джерел його генерації. Встановлено кореляційний звязок між коефіцієнтом тертя і значеннями пік-фактора кластера К2, коефіцієнт кореляції $\mathrm{r}=0,99$, а також швидкістю об'ємного зношування і значеннями пік-фактора кластера К3, коефіцієнт кореляції $\mathrm{r}=0,99$. Значення пік-фактора кластера К4 корелює зі швидкістю об'ємного зношування під час припрацювання, коефіцієнт кореляції $\mathrm{r}=0,98$.

Експериментальним шляхом доведено, що кластерний аналіз сигналів акустичної емісії з зони тертя трибосистеми дозволяє ідентифікувати поверхневі процеси під час зношування, тим самим підвищити робастність і інформативність методу АЕ. Даний аналіз може бути основою для розробки методики діагностування трибосистем під час їх експлуатації, що дозволить вимірювати швидкість зношування в будьякий момент часу і розраховувати ресурс трибосистеми.

Ключові слова: трибосистема; швидкість зношування; коефіцієнт тертя; акустична емісія; кластерний аналіз; пік-фактор; перехідні процеси; припрацювання. 